\title{
ASMENŲ, PATYRUSIŲ MIOKARDO INFARKTĄ, SAVARANKIŠKUMO, FUNKCINIO AKTYVUMO IR POŽIŪRIO İ SAVE POKYČIAI STACIONARINIO GYDYMO LAIKOTARPIU IR NAMUOSE
}

\author{
Evelina Lamsodienė, Gedvilė Juškytė \\ Kauno kolegijos Medicinos fakultetas
}

Raktažodžiai: miokardo infarktas (MI), savarankiškumas, fizinis pajègumas, funkcinis aktyvumas, veikla, požiūris ị save.

\section{Santrauka}

Statistikos duomenimis, kasmet Lietuvoje diagnozuojama apie 8 tūkst. miokardo infarkto atvejų. Po miokardo infarkto žmogaus organizmui nepajëgiant kompensuoti sutrikusios funkcijos, pastebimai pablogèja žmogaus veikla ir gyvenimo kokybè - pasireiškia negalia. Trinkant kraujotakai, pablogejja fizinio krūvio toleravimas, mažeja darbingumas, sunkiau pritapti prie aplinkos.

Apžvelgus literatūrą ir norint pasiekti iškeltą tikslą, tyrimas atliktas fenomenologinio tyrimo metodo pagrindu. Duomenų rinkimui taikytas pusiau struktūrizuotas interviu. Interviu apèmé tris pagrindines sritis: asmenų, patyrusių MI, savarankiškumo, funkcinio aktyvumo ir požiūrio ị save pokyčiai stacionarinio gydymo laikotarpiu ir namuose. Buvo sudarytas klausimynas. Su respondentais susitikta tris kartus. Visų trijų susitikimų metu kiekvieno asmens buvo prašoma atsakyti i keturis klausimus: 1 . Kaip pasikeite jūsų savarankiškumas kasdieninèje veikloje, ištikus miokardo infarktui? 2. Kaip pakito jūsų fizinis aktyvumas, atliekant ịprastines kasdienines veiklas? 3. Kaip pakito jūsų požiūris ị save ir savo veiklos galimybes, ištikus miokardo infarktui? 4. Kokią įtaką turès miokardo infarktas jūsų darbinei veiklai ir laisvalaikiui? Respondentams buvo užduodami nenumatyti iš anksto, tačiau asmenis išsamesniam pasakojimui atsiverti skatinantys klausimai. Tikslingoje tiriamujų atrankoje buvo laikomasi šių reikalavimų: pirmas - dalyvauti apklausoje buvo kviečiami asmenys, kuriems diagnozuotas MI ne vèliau negu prieš 48 valandas, antras - asmenys, besigydantys LSMUL I kardiologijos skyriuje
2015 m. balandžio mènesị, trečias - asmenys, kurie po stacionarinio gydymo vyksta i namus, ketvirtas - asmenys, visiškai suvokiantys situaciją ir besiorientuojantys aplinkoje, savyje ir laike. Iš viso tyrime dalyvavo 6 asmenys, kurių amžius nuo 45 iki 69 metų (amžiaus vidurkis 57,5 m.). Pacientams buvo paaiškinta apie tyrimą, jo tikslą, eigą ir paprašyta kontaktinio telefono numerio, kad būtų galima susisiekti ir susitarti dèl susitikimo išvykus iš stacionaro. Pokalbis su tiriamaisiais vidutiniškai trukdavo 10 minučių, pokalbiai buvo ịrašinèjami ị diktofoną, o po to, atliekant duomenu analizę, transkribuojami. Pirmieji du susitikimai vyko skyriuje, palatose, kuriose jie gulejo. Trečiasis susitartoje vietoje, kurią buvo patogu pasiekti abiem pusèm. Pirmasis susitikimas vyko ne vèliau nei 48 val., kai pacientas buvo paguldytas ị stacionarą. Antrasis - paciento išvykimo dieną iš stacionaro (stacionarizavimo vidurkis 7 dienos). Trečiasis - po 7-8 dienų, praleistų namuose. Tyrime dalyvavę asmenys kiekvieno interviu metu išskyrè, kaip keitèsi jų savarankiškumas, fizinis pajègumas ir požiūris ị save po miokardo infarkto, ịvairiais sveikimo periodais. Pirminio kodavimo metu buvo išskirta daug potemių, kurios sugrupuotos i 15 potemių, sugalvojant joms tikslingus pavadinimus. Vèliau kiekviena potemè buvo priskirta 3 didžiosioms temoms: a) savarankiškumo kaita; b) fizinio pajègumo pokyčiai; c) mintys, jausmai, emocijos. Tyrime dalyvavę asmenys per pirmas dvi paras po MI išsakè nejaučiantys didelių pokyčių savarankiškai atliekant kasdienines veiklas, bet pripažino, kad sunku realiai vertinti savo galimybes dèl fizinès veiklos stygiaus stacionare. Asmenys po MI dar gulèdami ligoninèje ịvardijo jaučiantys nerimą dèl ateities, sveikatos pokyčius ị blogają pusę, vis dažniau apimančias abejones dèl veiklų atlikimo ateityje ir neigiamas mintis, aplankančias dèl užim- 
tumo stokos. Sveikstant po MI tarp apklausoje dalyvavusiụjų išryškejjo tiek teigiamas, tiek neigiamas požiūris ị save. Grįžus ị namus, apklaustieji galejo ịvertinti, kad sumažejo jų fizinis pajègumas, priverčiantis juos rinktis lengvesnius darbus arba letinti veiklų atlikimo tempą. Taip pat daugeliui teko keisti laisvalaikio ịpročius, renkantis pasyvesnes veiklas.

\section{Ivadas}

Remiantis Lietuvos SAM duomenimis, Lietuvos gyventojų mirtingumo struktūra pagal pagrindines mirčiu priežastis jau daugelị metų išlieka nepakitusi. Trys pagrindinès mirties priežastys - kraujotakos sistemos ligos, piktybiniai navikai ir išorinès mirties priežastys $2012 \mathrm{~m}$. sudare 85,1 proc. visų mirusiujų. Nuo kraujotakos sistemos ligų mirè daugiau nei pusè, t.y. 56,6 proc. Didžiausią mirusiuju nuo kraujotakos sistemos ligų dalị sudare asmenys, mirę nuo išeminès širdies ligos ( 64,7 proc.) bei cerebrovaskulinių ligų (24,4 proc.). Didžioji dalis ( 85,1 proc.) mirusiujų nuo kraujotakos sistemos ligų buvo 65 metų ir vyresnio amžiaus asmenys [1].

Ūmus miokardo infarktas (MI) gali paskatinti sveikatos būklès pablogejjimą, ịskaitant savarankiškumo ir fizinių funkcijų sumažejimą. Nepaisant to, šių pasekmių svarba sveikimo prognozei ir gyvenimo kokybei, jų paplitimas ir faktoriai dar nèra gerai išanalizuoti [13].

$2012 \mathrm{~m}$. JAV atlikto tyrimo metu buvo analizuojama daugiau nei 2 tūkst. asmenų savarankiškumas ir fizinè būklè, praejjus 1 metams po persirgto MI. Tyrimo rezultatai parodè, kad net daugiau nei $40 \%$ pacientu patiria savarankiškumo praradimą ar fizinès būklès pablogejimą pirmus metus po MI. Šie pokyčiai pasireiškia atskirai, tačiau gali atsirasti ir vienu metu. Vienų rizikos veiksnių neimanoma modifikuoti, kiti rodo galimus tikslus strategijoms: kaip išsaugoti geresnę pacientų sveikatos būklę [11].

Nuovargis yra dažniausias ir labiausiai varginantis simptomas po miokardo infarkto, turintis neigiamos itakos su sveikata susijusiai gyvenimo kokybei [5].

Po MI organizmui nepajejgiant kompensuoti sutrikusios funkcijos, pastebimai pablogejja žmogaus veikla ir gyvenimo kokybe - pasireiškia negalia. Trinkant kraujotakai, pablogèja fizinio krūvio toleravimas, mažèja darbingumas, sunkiau pritapti prie aplinkos [8].

Visaapimantis nuovargis, besitęsiantis du ménesius po miokardo infarkto (Fredriksson-Larsson U., 2015), buvo susijęs su vienu metu kamuojančiais simptomais, pavyzdžiui, dusuliu ir stresu, ir ịveikos strategijomis, pvz., vertybių pasikeitimu, atsiskyrimu (vienišumu). Lyginant jaučiamo nuovargio matavimo rezultatus (bendras nuovargis, fizinis nuovargis, sumažejęs aktyvumas ir protinis nuovargis) praejjus dviem mėnesiams po miokardo infarkto su pradiniais duomenimis (tyrimas atliktas pirmą savaitę ligoninèje), jie parodè, kad nuovargio lygis sumažèjo. Viso tyrimo, trukusio keturis mènesius po miokardo infarkto, metu buvo nustatyta, kad du mėnesius po miokardo infarkto tiriamojoje grupeje buvo mažesnis nuovargio lygis [5].

Depresija po MI yra paplitusi, bet nepakankamai atpažistama ir turi stiprią įtaką tolimesnei ligos prognozei (Larsen K.K., 2013). Maždaug vienas iš penkių pacientuc tris mènesius po MI serga depresija. Siūloma patikra dèl depresijos, bet šių rekomendacijų laikosi ne visos gydymo ìstaigos. Šiuo tyrimu buvo nustatyta, kad didele dalis tų, kurie sirgo depresija po MI, prieš tyrimą depresija pacientams nebuvo diagnozuota. MI padidina savižudybès riziką, depresija po MI susilpnina bendrą sveikimo prognozę. Tyrimas rodo, kad fizinis aktyvumas ir antidepresantai keičia neigiamą prognozę pacientams, sergantiems depresija po MI, teigiamai, bet yra reikalingi tolimesni tyrimai, siekiant išsiaiškinti šių veiksnių galimą poveikị ir ịvertinti, kaip jie gali būti įtraukti ị pacientu po MI, turinčių depresiją, gydymą [6].

Efektyvus nerimo valdymas teigiamai veikia pacientu sveikimo rezultatus ir turètų būti taikomas visiems intensyviosios terapijos pacientams po MI [7].

Fizinio aktyvumo didinimas palankiai veikia sveikatą. Net ir nedidelio intensyvumo fizinio aktyvumo poveikis padeda, o fiziškai aktyvesniems galima būti visur, net darbo vietoje, pvz., nesinaudoti liftu, bet lipti laiptais [8].

Nuovargio vertinimas du menesius po miokardo infarkto leistų sveikatos priežiūros specialistams identifikuoti asmenis, kurie patiria nuovargi ir pasiūlyti nuovargio ribojimo programą. Individuali reabilitacijos programa turètų apimti streso valdymo ir dusulio ribojimo programą. Jei netinkamai naudojamos krizès įveikimo strategijos, pastebimas pacientų atsiskyrimas, šios strategijos turètų būti apsvarstomos kartu su pacientu [5].

Carney R.M. ir kt. JAV atlikto tyrimo metu išsiaiškinta, kad depresija yra nepriklausomas rizikos faktorius mirtims po ūmaus MI, tačiau ji neturi reikšmingos įtakos mirtingumui iki 12 mènesių po MI, depresija taip pat nebuvo pasikartojančio MI priežastimi [9].

Sveikimo prognozė po MI (Welin C., Lappas G., 2000) yra reikšmingai susijusi su asmens amžiumi, šeimine padètimi, išsilavinimu, papildomu darbu, protine įtampa darbe ar santuokoje, nerimu, nepasitenkinimu šeimos gyvenimu, problemomis, susijusiomis su vaikais, nepasitenkinimu finansine padètimi, gyvenimo nutikimais, vidiniu pykčiu, dirglumu, A tipo elgesiu ar savo sveikatos padèties valdymu. Be žinomų somatinių prognozės kintamųų po miokardo infarkto, prognozė taip pat labai priklauso nuo depresi- 
jos ir socialinès paramos trūkumo, o ne nuo kitų psichosocialinių veiksnių [12].

Švedijoje atlikto kokybinio tyrimo metu (Kristofferzon M.L. ir kt., 2007), taikant interviu metodą, buvo apklausta 20 moterų ir 19 vyrų. Juo buvo siekiama išsiaiškinti kasdieninio gyvenimo potyrius, praejjus 4-6 mèn. po MI. Analizuojant atliktus interviu, buvo išskirtos trys didžiosios temos: „Grèsmès įprastam gyvenimui““, „Kova už kontrolę“ ir „Neapibrèžtas paramos tinklas“ (tai paramos tinklas, kurị gali sudaryti įvairios grupès, pvz., šeima, giminès, benduomene, sveikatos priežiūros įstaigų darbuotojai ir kt.). Dažniausios įvardijamos problemos pirmaisiais mènesiais po miokardo infarkto buvo fiziniai simptomai ir emocinis stresas. Respondentai buvo linkę valdyti problemas, derèdamiesi su savimi, remdamiesi savo paties galimybemis, keite požiūrị ir elgesị, patys priimdavo sprendimus ir veiksmus. Paramos tinklas teikè palaikymą, bet taip pat dažnai respondentai patyrè bendravimo problemų, bendraudami su savo tinklu. Moterys ir vyrai po miokardo infarkto stengiasi išlaikyti pusiausvyrą tarp problemų ir išteklių kasdieniniame gyvenime. Kaip gerai jiems tai pavykdavo priklausè nuo to, ar jie jautėsi saugūs, kaip gerai jie išsakẻ savo poreikius paramos tinklui ir ar jautrus buvo tinklas jų išsakytiems ir neišsakytiems poreikiams [10].

Tyrimo tikslas - išanalizuoti asmenų, patyrusių miokardo infarktą, savarankiškumo, funkcinio pajègumo ir požiūrio ị save pokyčius stacionarinio gydymo laikotarpiu ir namuose.

\section{Tyrimo objektas ir metodika}

Apžvelgus literatūrą ir norint pasiekti iškeltą tikslą, tyrimas atliktas fenomenologinio tyrimo metodo pagrindu. Duomenų rinkimui taikytas pusiau struktūrizuotas interviu. Interviu apèmè tris pagrindines sritis:

- Asmenų, patyrusių MI, savarankiškumo pokyčiai stacionarinio gydymo laikotarpiu ir namuose.

- Asmenų, patyrusių MI, funkcinio aktyvumo pokyčiai stacionarinio gydymo laikotarpiu ir namuose.

- Asmenų, patyrusių MI, požiūrio ị save pokyčiai stacionarinio gydymo laikotarpiu ir namuose.

Šio metodo principu buvo sudarytas klausimynas. Su respondentais susitikta tris kartus. Visų trijų susitikimų metu kiekvieno asmens buvo prašoma atsakyti ị keturis klausimus:

- Kaip pasikeitè jūsų savarankiškumas kasdieninèje veikloje, ištikus miokardo infarktui?

- Kaip pakito jūsų fizinis aktyvumas, atliekant iprastines veiklas?

- Kaip pakito jūsų požiūris ị save ir savo veiklos galimybes, ištikus miokardo infarktui?

- Kokią ittaką turès miokardo infarktas jūsų darbinei veiklai ir laisvalaikiui?

Respondentams buvo užduodami nenumatyti iš anksto, tačiau asmenis išsamesniam pasakojimui skatinantys klausimai.

Tiriamieji buvo atrinkti, kad atitiktų kokybinių tyrimų atlikimo reikalavimus. Tikslingoje tiriamujų atrankoje buvo laikomasi šių reikalavimų: pirmas - dalyvauti apklausoje buvo kviečiami asmenys, kuriems diagnozuotas MI ne seniau negu prieš 48 valandas, antras - asmenys, besigydantys LSMUL I kardiologijos skyriuje $2015 \mathrm{~m}$. balandžio mènesi, trečias - asmenys, kurie po stacionarinio gydymo vyksta ị namus, ketvirtas - asmenys, pilnai suvokiantys situaciją ir besiorientuojantys aplinkoje, savyje ir laike. Iš viso tyrime dalyvavo 6 asmenys, kurių amžius nuo 45 iki 69 metụ (amžiaus vidurkis 57,5m.). Pagal lytị tiriamieji pasiskirste tolygiai - 3 vyrai ir 3 moterys. Tiriamujų profesijos buvo įvairios: suvirintojas, globejja, krovejas, valytoja ir du nedirbantys - gaunantys senatvès pensiją. Visi tiriamieji patyrẻ MI, tačiau skirtingų lokalizacijų. Detalesné tiriamųjų charakteristika pateikta 1-oje lentelèje.

Bendraujant su pacientas ir bendradarbiaujant su personalo darbuotojais buvo vertinama, ar jie suvokia situaciją bei ar orientuojasi aplinkoje, savyje ir laike. Prieš pradedant pokalbị buvo išsiaiškinama, ar sutiks duoti interviu pakartotinai, grįžę i namus. Buvo paaiškinta, kad nei jų kontaktinè informaciją, nei pavardès nebus viešinami ir garantuojamas konfidencialumas (vardai pakeisti). Pacientams buvo paaiškinta apie tyrimą, jo tikslą, eigą ir paprašyta duoti savo kontaktinị telefono numerị, kad būtų galima susisiekti ir susitarti dèl susitikimo išvykus iš stacionaro. Pacientams išvykus iš stacionaro, dèl susitikimo su jais buvo tariamasi telefonu. Pokalbis su tiriamaisiais vidutiniškai trukdavo 20 minučių, pokalbiai buvo įrašinejjami ị diktofoną, o po to, atliekant duomenų analizę, transkribuojami. Pirmieji du susitikimai vyko skyriuje, palatose, kuriose jie gulejo. Trečiasis susitartoje vietoje, kurią buvo patogu pasiekti abiem pusėm. Pirmasis susitikimas vyko ne vèliau kaip 48 val., kai pacientas buvo paguldytas ị stacionarą. Antrasis - paciento

1 lentelè. Tiriamųų charakteristikos

\begin{tabular}{|l|l|l|l|l|}
\hline Nr. & Vardas & Amžius & Diagnozė & Specialybė \\
\hline 1. & Stasys & 45 & I21.2 & Suvirintojas \\
\hline 2. & Gražina & 53 & $\mathrm{I} 21.0$ & Globėja \\
\hline 3. & Alfreda & 59 & $\mathrm{I} 21.4$ & Valytoja \\
\hline 4. & Jonas & 68 & $\mathrm{I} 21.4$ & Nedirba \\
\hline 5. & Evaldas & 51 & $\mathrm{I} 21.1$ & Krovèjas \\
\hline 6. & Sofija & 69 & $\mathrm{I} 21.0$ & Nedirba \\
\hline
\end{tabular}


išvykimo dieną iš stacionaro (stacionarizavimo vidurkis 7 dienos). Trečiasis - po 7-8 dienų, praleistų namuose. Prieš kiekvieną pokalbị buvo primenama apie tyrimą, jo tikslą ir eigą. Pokalbiai su pacientais buvo įrašomi. Buvo paaiškinta, kad pokalbių įrašai taip pat nebus viešinami ir yra reikalingi tik norint užtikrinti informacijos tikslumą. Visi tiriamieji žodžiu sutiko dalyvauti tyrime.

Kokybiniams tyrimams dažniausiai naudojama indukcinè duomenų analizè, o tyrimo rezultatai pateikiami aprašomuoju būdu, iliustruojant juos raiškia respondentų kalba. Kokybiniai tyrimai apima didelę ịvairovę kontekstualizuotų tradicijų, strategijų, metodų. Pagrindinès, tradicinès kokybinių tyrimų metodologinès strategijos yra atvejo tyrimas, etnografinis tyrimas, fenomenologinis tyrimas, naratyvinis tyrimas, pagrịstoji teorija, turinio analizè ir veiklos tyrimas. Vienas iš kokybinio tyrimo metodų yra fenomenologinis tyrimas.

Fenomenologiniu tyrimu siekiama aprašyti, suprasti, kaip skirtingi individai patiria tam tikrą reiškinị (fenomeną), kokias prasmes suteikia tam reiškiniui. Fenomenologija yra teorinis požiūris, kuriuo siekiama generuoti žinias, kaip žmonès patiria reiškinius [4]. Tyrèjo dėmesio centre - ne individai, bet reiškinys ir tai, kaip tas reiškinys yra patiriamas skirtingų individų. Tyrèjas ieško to, kas bendra skirtingose individų patirtyse, to, ką visi individai patiria susidūrę su reiškiniu. Ta bendra patirtis, o ne išankstinès tyrejjo žinios apie reiškinị kaip realybès dalị, ir yra reiškinio esmè. Fenomenologiniuose tyrimuose gali būti analizuojamos patirtys, susijusios su tokiais reiškiniais kaip nemiga, pyktis, sielvartas ir pan. Tyrejjas renka duomenis iš asmenų, patyrusių tą reiškinị, ir analizuoja ką ir kaip jie patyrè.

Tyrèjai rašo tyrimo klausimus, noreddami ištirti šios patirties prasmę asmenims, ir jie prašo asmenis apibūdinti savo kasdienius ,gyvenimo“ patyrimus. Paprastai ši informacija yra renkama per interviu [3].

Richard Boyatzis aprašo penkis tematinès analizès (angl. Thematic analysis) tikslus: tai yra matymo, ryšių sudarymo, analizès, sistemingo atvejo stebejjimo ir kiekybiško kokybinių duomenų ịvertinimo. Platūs duomenų šaltiniai gali būti naudojami tematinès analizès, iskaitant interviu nuorašus, lauko pastabos, informaciją, parašytą dalyvių (dienoraščiai ir kt.) [2].

Pagrindinè analitinè strategija naudojama tematinejje analizèje yra kodavimas, procesas glaudžiai tikrina tekstą, ieškant pasikartojančių temų, potemių ar tarpusavio ryšių, ir ženklina panašias ištraukas kodais arba etiketemis, kategorizuojančiomis juos vėlesnei paieškai ir teorijos kūrimui. Temų identifikavimas gali vykti deduktyviai, remiantis teoriniu pagrindu, kuri atvejo studijos tyrejjas pasirinko [2].

\section{Tyrimo rezultatai ir jų aptarimas}

Tyrime dalyvavę asmenys kiekvieno interviu metu išskyrè kaip keitèsi jų savarankiškumas, fizinis pajejgumas ir požiūris ị save po miokardo infarkto skirtingais sveikimo periodais. Pirminio kodavimo metu buvo išskirta daug potemių, kurios sugrupuotos i 15 potemių, sugalvojant joms tikslingus pavadinimus. Vèliau kiekviena potemè buvo priskirta 3 didžiosioms temoms (savarankiškumo kaita; fizinio pajègumo pokyčiai; mintys, jausmai, emocijos). Temos

2 lentelè. Interviu metu išryškèjusios pagrindinès temos ir potemès

\begin{tabular}{|c|c|c|c|}
\hline \multirow[b]{2}{*}{ DIDŽIOSIOS TEMOS } & \multicolumn{3}{|c|}{ POTEMĖS } \\
\hline & $\begin{array}{c}1 \text { inter- } \\
\text { viu }\end{array}$ & $\begin{array}{l}2 \text { inter- } \\
\text { viu }\end{array}$ & $\begin{array}{l}3 \text { inter- } \\
\text { viu }\end{array}$ \\
\hline \multicolumn{4}{|l|}{$\begin{array}{l}\text { SAVARANKIŠKUMO } \\
\text { KAITA }\end{array}$} \\
\hline Savarankiškumo pokyčiai & $\checkmark$ & - & - \\
\hline Renkasi lengvesnius darbus & - & - & $\checkmark$ \\
\hline $\begin{array}{l}\text { Sulètejęs tu pačių veiklų } \\
\text { atlikimas }\end{array}$ & - & - & $\checkmark$ \\
\hline \multicolumn{4}{|l|}{$\begin{array}{l}\text { FIZINIO PAJËGUMO PO- } \\
\text { KYČIAI }\end{array}$} \\
\hline Fizinès veiklos stoka & $\checkmark$ & - & $\checkmark$ \\
\hline $\begin{array}{l}\text { Fizinio pajègumo sumažè- } \\
\text { jimas }\end{array}$ & $\checkmark$ & $\checkmark$ & $\checkmark$ \\
\hline $\begin{array}{l}\text { Sveikatos pokyčiai ị blogają } \\
\text { pusę }\end{array}$ & $\checkmark$ & $\checkmark$ & $\checkmark$ \\
\hline Pasyvus laisvalaikis & - & - & $\checkmark$ \\
\hline \multicolumn{4}{|l|}{$\begin{array}{l}\text { MINTYS, JAUSMAI, EMO- } \\
\text { CIJOS }\end{array}$} \\
\hline Nerimas dèl ateities & $\checkmark$ & $\checkmark$ & - \\
\hline $\begin{array}{l}\text { Neigiamos mintys dèl užim- } \\
\text { tumo stokos }\end{array}$ & - & $\checkmark$ & - \\
\hline Savijautos pokyčiai & $\checkmark$ & $\checkmark$ & $\checkmark$ \\
\hline $\begin{array}{l}\text { Abejonès dèl veiklų atlikimo } \\
\text { ateityje }\end{array}$ & $\checkmark$ & $\checkmark$ & - \\
\hline Baimè - nieko negalèti & $\checkmark$ & $\checkmark$ & - \\
\hline Neigiamas požiūris ị save & - & $\checkmark$ & $\checkmark$ \\
\hline Teigiamas savęs vertinimas & - & $\checkmark$ & $\checkmark$ \\
\hline Noras grižžti ị darbą & - & $\checkmark$ & $\checkmark$ \\
\hline
\end{tabular}


ir potemès pateiktos 2-oje lentelejje.

1. Savarankiškumo kaita. Pirmoji išryškejjusi tema apėmė respondentų interviu atsakymus, apibūdinančius, kaip keitèsi jų savarankiškumas persirgus MI. Kaip kito jų galimybės atlikti veiklas kasdieniniame gyvenime, darbinejje veikloje ar laisvalaikio metu.

Savarankiškumo pokyčiai - respondentai pirmojo interviu metu teigè nejaučiantys savarankiškumo pokyčiu kasdieninèse veiklose po ištikusio MI, tačiau nėra tuo užtikrinti dèl veiklos stokos stacionare.

„Dar dabar i visuomenini gyvenima neisiliejau po miokardo infarkto. Kiek čia teveikiu, tai po kol kas lyg niekas nepasikeite, kaip iki tol buvo, taip ir dabar." (1 pac. 1 interviu)

„,Nepasikeité niekas žinokit, jaučiuosi taip pat.“ (6 pac. 1 interviu)

Renkasi lengvesnius darbus - trečiojo interviu metu išryškejjo, kad respondentai, grịžę namo prie savo ịprastos kasdienès veiklos, renkasi lengvesnius darbus negu prieš patirtą MI, tai rodo jų fizinio pajègumo sumažèjimą.

„Nebeturiu tiek sveikatos ir tiek darbu nebeapsiimu, bet dékui Dievui bent kažkiek dar galiu. " (1 pac. 3 interviu)

„Kur dirbau rimtus darbus namuose, o kur dabar tolygiai su žmona dirbu tuos, taip tariant nevyriškus, darbus. Namai visada pašildyti, aptvarkyti, valgyti padaryta, vaikštau švarus, bet va norisi ir stogo latakus išsivalyti, pabetonuoti laiptu aikštelę, bet nedristu. O ir šiaip ieškosiuosi lengvesnio darbo, nes tokiomis salygomis kaip kad dirbu dabartinam darbe man jau pavojinga yra su tokia širdim. "(5 pac. 3 interviu)

„Yra to darbo namuose ir aplink juos, vyras po insulto, aš irgi nebe tokia žvali kaip kad buvau, greitis ir ištverme nebe tie, todèl užteks eikvoti save ir lenkti nugara dèl kitu, pradèsiu gyventi sau. " (3 pac. 3 interviu)

„Vardan sveikatos geriau apsiribosiu mažesniais darbeliais tik dažniau. "(2 pac. 3 interviu)

„Bet vat va ejjau bandyti pats koki kilima ištempti lauk ar malku parvilkti - be šansu žinokit. Nu kaip čia jums pasakius, padaryt padarau, bet tada gailiuosi tai nuveikęs, nes dievaži kaip atima visa energiją. Ka jau kalbèti apie rimtesnius darbus prie namo, ten iš viso teks juos užmiršti. "(4 pac. 3 interviu)

Sulètejęs tų pačiu veiklų atlikimas - trečiojo interviu metu taip pat išryškèjo, kad respondentai, grịžę namo, kasdieneje veikloje renkasi ne tik lengvesnius darbus, bet ir atlieka juos lèčiau negu prieš patiriant MI, o tai dar labiau pabrèžia fizinio pajègumo sumažejjimą.

„,Tenka saugotis ir atlikinèti viska léčiau, ir apsvarstyti, ar tam tikri darbai yra mano jègoms. Tik, savaime aišku, viska darau léčiau ir pertraukèliu pasidarau, nes vis tiek širdelè nebe tokia, kokia buvo ir reikia ja prižiūrèti. "(1 pac. 3 interviu)

„Susilpnejau stipriai, tai veiksmas irgi dingo. O pats save prisižiūriu pilnai, tik apsukos stipriai mažesnès, nes sveikata nebe ta." (4 pac. 3 interviu)

„Visas judesys dabar lètesnis, darbeliai mažesni, bet noras judèti didesnis už viska, todèl džiangiuosi tuo ka turiu. " (2 pac. 3 interviu)

„Aišku, būna, kad iš ipročio pradedi senuoju tempu varyti, bet kai pritrūksta kvapo, pailsi ir toliau tęsi léčiau ir viskas puikiai būna. Jei per greitai imu darbuotis, užima kvapa. Per gyvenima priskubejau jau - tai štai ir rezultatas, gana bègti visur, laikas leisti sau viska daryti léčiau, atsakingiau ir su didesniu malonumu. Lètesnis žmogus pasidariau ir tiek. "(3 pac. 3 interviu)

2. Fizinio pajègumo pokyčiai - antrosios išryškejjusios temos metu respondentų atsakymuose dominuoja asmenų, persirgusių MI, fizinès veiklos atlikimo galimybių pokyčiai ar negalejjimas ịvertinti savo galimybių.

Fizinės veiklos stoka - respondentai teigia, jaučiantys fizinès veiklos stoką stacionarinio gydymo laikotarpiu, dèl to nèra užtikrinti, kaip bus tolesniame jų gyvenime, grįžus prie ịprastos veiklos namuose.

„,Jokiu pasikeitimu kol kas nepastebiu, nes čia labai mažai turim galimybiu judèjimui, prie kokiu esam pratę. Kaip bus toliau gyvenimas parodys, nes šiuo metu per mažai kažka dariau, kad galèčiau atsakyti. "(1 pac. 1 interviu)

„Ligoninej mes čia nieko per daug negalim." (3 pac. 1 interviu)

„Dabar jaučiuosi gerai ir pakankamai sveika, bet tai tik spejjimai, nes mes čia nejudam, o tik vegetuojam. " (6 pac. 1 interviu)

Fizinio pajègumo sumažejimas - respondentai antrojo ir trečiojo interviu metu teigia jaučiantys fizinio pajègumo sumažèjimą, atliekant fizinę veiklą, nes judant ar dirbant iprastas veiklas, kuriomis užsiimdavo prieš patiriant MI, jaučia, kad nebegali to atlikti arba tai atlikti pasidarè sunkiau.

„,Kaip ana karta maniau kad, jei neklystu, tik 30 proc jègu teliko, va dabar 50 proc. duočiau, nu bet va daugiau tai niekaip negalèčiau duoti. Kai bandžiau nueiti su vyrukais iki kavinès, jau pusiaukèlèj apsisukau ir su dižiausiom pertraukom vos pargrižau. "(4 pac. 2 interviu)

„Nu baisu žinokit kažka ir veikti dabar rimčiau, ir tikrai bijosiu dar namuose. Bandysiu po biški, bet ar kas gausis, tai jau nežinau. " (5 pac. 2 interviu)

„Aš suprantu, kad vaizduoju čia kokia sveika esu ir viskas gali pasikeisti, kai krūvis stipriai padidès, bet noriu tikèti, kad viskas bus gerai ir galèsiu toliau varyti. "(6 pac. 2 interviu) 
„Bet neslèpsiu, kad darbo krūvį susimažinau ir ačiū Dievui kolegos nemažai padeda, nes yra momentu kur reikia daug fizinès jégos. "(1 pac. 3 interviu)

„Ir dabar pietu miego visada einu bent valandèlei jeggu atstatymui, nes ju stygius jaučiasi. "(3 pac. 3 interviu)

„Energijos nebeturiu kiek buvo, jégos ir tos dingo. “ (4 pac. 3 interviu)

„Poilsio minutèliu stipriai padaugèjo dabar pas mane, nors darbai palengvejo. " (5 pac. 3 interviu)

Sveikatos pokyčiai ị blogają pusę - daugiausia pirmojo interviu metu respondentai po patirto MI teige jaučiantys neigiamus pokyčius savo sveikatoje, atliekant kasdienes veiklas, tam turejjo įtakos ir fizinio pajègumo sumažèjimas.

„Nu tam trukdo toks galvos silpnumas, nes tos dienos vis tiek kelios išguletos reanimaciniam. Tai dabar ta galva kažko tai kaip ir sukasi, bet tai nieko. " (2 pac. 1 interviu)

„,Matot, kaip jums čia pasakyti, ar valaisi, ar prausiesi jau pavargsti" (4 pac. 1 interviu)

„Tikejausi, kad bus blogiau, bet rezultatai taipogi nedžiugina. Suprantu, kad galètu büti ir blogiau, bet tokie mes žmonès esam, kad visada norime daugiau negu galime. "(5 pac. 1 interviu)

„Ir va biški pavaikštai su palatos kolegom, aišku savaime, jaunesni jie, bet vis tiek jau jaučiu, kad man silpna. Dusina, silpstu, glembu kaip vikšras. Noriu kuo daugiau, bet vat kad nieko ir nebeliko. " (4 pac. 1 interviu)

„Su kiekviena diena viskas keičiasi ir nepasakyčiau, kad i gera. " (1 pac. 2 interviu). „,Bet ne tiek pinigine prasme, kiek man pačiam trūksta visu tu darbu. Deja - nebegaliu, sveikata neleidžia tęsti. "(4 pac. 3 interviu)

Pasyvus laisvalaikis - respondentai, po ištikusio MI ir grižę namo, trečiojo interviu metu teigè besirenkantys pasyvų laisvalaikị, kuriam turi ịtakos fizinio pajègumo sumažèjimas ir savęs saugojimas.

„O laisva laika pradejjau leisti lovoje, vaikštant arba krapštantis prie mašinos palengva. Nieko, stengiuosi bent kol kas su judesiu neveikti. “(1 pac. 3 interviu)

„,Užtat kai neužsièmusi būnu, stengiuosi domètis viskuo, kas susije su gijimo greitinimu, kaip gyventi, kad tai nebesikartotu. Pasiilsiu per ta laika, o tuo pačiu-paprotingèju. "(2 pac. 3 interviu)

„Nu laisvalaikiu, tiesiai šviesiai pasakius - tinginiauju. Norisi to poilsio, o jo ir reikia. "(3 pac. 3 interviu)

„O tinginiavimo metu ir tinginiauju tiesiogine ta žodžio prasme. Dabar mano geriausius draugus - soda, dvirati pakeite televizorius, lova ir šaldytuvas. "(4 pac. 3 interviu)

„Bet kol kas laisvu laiku stengiuosi ilsètis kuo daugiau. "(5 pac. 3 interviu)

3. Mintys, jausmai, emocijos - trečioji išryškëjusi tema pati plačiausia. Ji apima norus, jausmus, baimes, lū- kesčius ir daugelị kitų emocijų, kurios atsiranda patyrus MI ir sveikimo laikotarpiu.

Nerimas dèl ateities - respondentai patyrę MI, pirmojo ir antrojo interviu metu ịvardija jaučiantys nerimą dèl to, kaip bus ateityje, grị̌us namo.

„Kad tas pats bus ir namie negaliu teigti, nes čia kelios dienos tiktai yra praejusios. Kaip bus pargrižus i namus, čia klausimas jau." (1 pac. 1 interviu)

„Niekas negimé tokiu protingu ir ì prieki numatančiu, kad žinotu, kaip bus namuose.“ (3 pac. 1 interviu) „,Ka keisti reikès, o tikiu kad reikès, tesužinosiu grįžusi i savo vieta ir gyvenimo judesi, visgi jauduliukas yra dèl to. " (6 pac. 1 interviu)

„Tik va kuo toliau, tuo labiau abejoju ir nervinuosi, kaip bus namuose. Labai laukiu, kol grišiu namo, bet kartu ir nerimas toks širdyje nejaukus apsigyveno. "(1 pac. 2 interviu)

„Seniau kaip konvejeris pro namus prasisukdavau, o dabar žiürèsiu, ar netapsiu pagedusiu traktoriuku. "(3 pac. 2 interviu)

„O po to visa diena griaužia kirmèle galvelej su mano baisiausiu klausimu: o kas gi bus, kai išejjus iš čia reikès grịžti i gyvenimo vagą? Tarsi viska galiu, bet kuo toliau, tuo labiau bijau. Nu baisu žinokit kažka ir veikti dabar rimčiau ir tikrai bijosiu dar namuose. " (5 pac. 2 interviu)

Neigiamos mintys dèl užimtumo stokos - respondentams, patyrusiems MI, stacionarinio gydymo laikotarpiu kyla neigiamų minčių dèl tolesnių savo veiklos galimybių, kurioms turi įtakos užimtumo stacionare stoka.

„Jau tiek prisigalvojau sau draudimu, nors savijauta kaip ir nieko. Kažkokia nesamonè, tas laikas čia itin žlugdo psichologiškai. Nes po tokio maksimalaus prisitinginiavimo vèl ị toki darba grižti visgi iššūkis net sveikam žmogui būtu. "(1 pac. 2 interviu)

„Kai mes čia turime itin per daug laiko galvojimui, tai patikèkit ko tik neprisigalvoju, jau net sapnuotis pradeda visos tos nesamones. " (2 pac. 2 interviu)

„,Jaučiuosi kaip ir gerai, kiek išeina, pats viska neblogai pasidarau, nu bet tos mintys, minteles. " (5 pac. 2 interviu)

„Ir dar tas laukimas ir nežinia tikrai neprideda sveikatos. Tas gulejimas šitose palatose, chlorkalkiu kvapas ir balti chalatai tikriausiai labiau žlugdo negu pati ta liga." (3 pac. 2 interviu)

„Čia laikas tarsi sustojo, nors galètu ir greičiau bègti, nes noriu pargrįžus namo issivertinti save, nes jau net man darosi idomiau nei jums, kas bus su manim ir keisis kas ar ne, o pasikeitimu noréčiau mažiausiai. "(1 pac. 2 interviu)

„Jūs man tik duokit tos fizinès veiklos ir aš jums kalnus nuversiu, nors ir suprantu, kad tai gali nepavykti. "(6 pac. 


\section{2 interviu)}

„Noriu tos veiklos, nes nebegaliu protiškai čia kirmyti, bet kai pagalvoju apie pasekmes, net negera darosi. “ (5 pac. 2 interviu)

Savijautos pokyčiai - vieni respondentai po patirto MI jaučia savijautoje pokyčius, kitų teigimu - jokių savijautos pasikeitimų nejaučiantys.

„Po tos operacijos, tos... zondavimo, pranyko šitai ir skausmai ir viskas, tai lygtais viskas taip pat kaip iki tol buvo. "(1 pac. 1 interviu)

„Dabar man kai ta procedūra padaré, taip zondavima, ir aš negaliu sakyti taip kad man kažkas blogai. Taip, man gerai, tikrai labai gerai. " (2 pac. 1 interviu)

„Šiaip tai man kol kas nieko nesijaučia, aš gyvenu nu normaliai, kaip gyvenau. "(3 pac. 1 interviu)

„Anksčiau tai dusindavo, tai užspausdavo, tai dar kas, ir tai tęsési gana ilga laika, o va kai ištiko mane tasai infarktas, padare kaip ten ta zondavima, nu super tiesiog. “ (5 pac. 1 interviu)

„Po to zondavimo man daug geriau ir niekuo skustis negaliu, bent jau paprastose švarinimosi procedūrose, nes kai pranyko skausmai, jaučiuosi kaip niekur nieko. "(1 pac. 2 interviu)

„Jeigu Dievulis duos tokiq sveikata ir namuose, kaip kad čia jaučinosi, tai tada tikrai galèsiu sakyti, kad esu sveika, nes dabar nič niekuo negaliu skustis kas liečia iprasta savęs prižiūrèjima. " (6 pac. 2 interviu) interviu)

„Nu tikrai gerai man jau, bent jau kol kas." (1 pac. 3

„,Kol kas tvarkausi po biški, niekur neskubu ir dèl to skustis negaliu. (3 pac. 3 interviu)

Abejonès dèl veiklų atlikimų ateityje - respondentams po patirto MI kyla abejonių dèl to, kaip seksis atlikti įprastines veiklas ateityje, ką reikès keisti ir kaip elgtis.

„Kažka tai reikès stabdyti, nu kažko tiek nedaryti per jéga. Tiesiog savo veikla riboti. " (1 pac. 1 interviu)

„Yra tik nežinomybè ir baimé, tai galéčiau tik spèlioti, o to itin nemègstu. Bet jaučiu gal gali büti kad vis tiek čia kažkas keisis, bus kitaip. Lyg tai kažko nedaryti, gali kažko kažkur neveikti, kq veikei. Kažko gali tekti atsisakyti" (3 pac. 1 interviu)

„Baisu net galvoti apie ateiti, kas bus toliau ir kaip viskas pasikeis." (4 pac. 1 interviu)

„Va mastysena daugiausia pasikeite. Kokia veikla reikès užsiimti, kaip reikès daryti ja, kaip reikès ten vasara praleisti, dirbti ar kaip seksis namie. Tenka pradeti galvoti, kaip reikia elgtis ir ka daryti kitaip, kad dar pagyvent neapsunkinant kitu. " (5 pac. 1 interviu)

„Dabar jaučiuosi gerai ir pakankamai sveika, bet tai tik spèjimai, nes mes čia nejudam, o tik vegetuojam, o kaip bus grižus ị namus, kur daugiau judesio, Dievulèlis težino. " (6 pac. 1 interviu)

„Ir va bijau to nesugebèti, nors kaip ir tikiu, kad galesiu darbuotis, bet prisikalbèti nenoriu dievaži. "(1 pac. 2 interviu)

Baimè - nieko negalèti - respondentams po ištikusio MI kyla baimès jausmas, kad gali nieko nebegalèti ar atlikti tai, ką sugebejo prieš patiriant MI.

„Bet atvirai kalbant tai dabar jaučiu baimę ir pats negaliu tiksliai suprasti kodèl." (1 pac. 1 interviu)

„Kaip čia pasakius, baisu pasidare." (3 pac. 1 interviu)

„O ka gero čia galima pasakyti, o nieko gero negaliu pasakyti. Labai sunku ir baisu dabar. Ka jau aš sugebésiu. "(4 pac. 1 interviu)

„Bijau, yra ta kažkokia baimé, nežinau dèl ko, bet bijau." (6 pac. 1 interviu)

„Ko tu gali būti vertas, kai čia vartaisi lovoj, nerviniesi ir bijai dèl visko, o padaryti kažko ar pakeisti negali, laiko atgalios tai neatsuksi." (5 pac. 2 interviu)

„Ir va bijau to nesugebèti, nors kaip ir tikiu, kad galesiu darbuotis. "(6 pac. 2 interviu)

Neigiamas požiūris ị save - antrojo interviu metu respondentų atsakymuose pastebimas neigiamas savęs vertinimas, kuriam turi ịtakos veiklos trūkumas stacionare.

„Net nemoku paaiškini jums, bet kaip ir jauti kad viskas neblogai, bet vis tiek save nuvertini ir galu gale gaunasi makalyne galvoje, kas nepadeda tikrai gijimui." (1 pac. 2 interviu)

„Čia ir dingsta mano optimizmas, kai tik lieku su savo mintimis viena ir baisiai pradedu save nuvertinti, nors suprantu, kad taip net nera. " (2 pac. 2 interviu)

„Čia bebūnant pradedi pats savęs nekęsti, tai koks dar gali būti savęs vertinimas. "( 3 pac. 2 interviu)

„Nes va pavyzdžiui pasakai kažka kaip yra, tai yra viena, bet kai suvoki, kad tai tavo gyvenimas, pradedi jaustis blogiau už nuotaka, kuria ka tik prie altoriaus, atsiprašant, apderge balandis. Va taip va ir jaučiuosi, jeigu kalbant buitiškai. " (4 pac. 2 interviu)

„Šiuo metu savęs kaip žmogaus nebevertinu. “(5 pac. 2 interviu)

„Kartais būna momentas, kai truputi nepilnavertis pasijaučiu, bet greitai ir grịžtu vèl i vèzes. "(1 pac. 3 interviu) „Dabar žmona kiek turès dirbti už mane. Išlaikytinis būsiu, aišku, ne pinigine prasme, nes, dèkui Dievui, dar pensija gaunu. Buvau šeimos galva, dabar esu šeimos našta. " (4 pac. 3 interviu)

„Nebesijaučiu naudingas tiek kiek galèjau büti seniau. Ir bailys šiek tiek pasidariau tam tikrais gyvenimo atvejais. "(5 pac. 3 interviu)

Teigiamas savęs vertinimas - respondentai po ištikusio 
MI vertina save ir savo galimybes ir teigiamai.

„Aišku esu laiminga, kad jaučiuosi sveika šiuo metu“"

(3 pac. 2 interviu)

„Nebeturiu tiek sveikatos ir tiek darbu nebeapsiemu,

bet dèkui Dievui bent kažkiek dar galiu. "(1 pac. 3 interviu)

„, Tikiu, kad esu tokia, kokia buvau ir esu dèl to laiminga" (6 pac. 3 interviu)

„O pats save prisižiūriu pilnai, tik apsukos stipriai mažesnès, nes sveikata nebe ta. "(4 pac. 3 interviu)

„Bet vis tiek dar galiu laikyti save pilnaverte moterimi. "(2 pac. 3 interviu)

Noras grịžti ị darbą - respondentai antrojo ir trečiojo interviu metu teigia norintys grịžti ị darbą, nes tai jiems yra svarbu ir daro juos laimingus bei visaverčius.

„Jeigu sugebèsiu grižti i darba, vadinasi, aš dar laimingas žmogus. " (1 pac. 2 interviu)

„Labai noriu sugebèti grižti ị darba, ir labai stengiuosi save ịtikinti, kad man pavyks, nors sekasi tai žinokit nekaip, nes tos dvejones ir nenoras patirti to dar karta labai stabdo. " (2 pac. 2 interviu)

„Ir dar problema yra didžiausia ta, kad mano malonumas didžiausias turbūt ir yra darbas, taigi jei prarasiu darba, prarasiu ir didelę dali savęs ir džiaugsmo. " (3 pac. 2 interviu)

„Kol esu darbingas, tol galiu didžiuotis savimi, todèl mano tikslas ir yra grįžti i darba. " (1 pac. 2 interviu)

„, Turèjau tiksla grižti ị darba, tai ir padariau. Dar pakankamai jaunas esu, norisi dirbi, o darbas irgi pagal pašaukima, tai nesinorètu jo keisti. Bet esu laimingas sugrižęs i darba. "(1 pac. 3 interviu)

„Bet noro sugrižti i darba netrūksta. “( 2 pac. 3 interviu)

\section{Išvados}

1. Tyrime dalyvavę asmenys per pirmas dvi paras po MI išsakė nejaučiantys didelių pokyčiu savarankiškai atliekant kasdienines veiklas, bet pripažino, kad sunku realiai vertinti savo galimybes dèl fizinès veiklos stygiaus stacionare.

2. Asmenys po MI dar gulèdami ligoninèje ịvardijo jaučiantys nerimą dèl ateities, sveikatos pokyčius ị blogają pusę, vis dažniau apimančias abejones dẻl veiklų ateityje ir neigiamas mintis, aplankančias dèl užimtumo stokos.

3. Sveikstant po MI, tarp apklausoje dalyvavusiujų išryškejjo tiek teigiamas, tiek neigiamas požiūris ị save: našta namiškiams ir kt.

4. Grịžus ị namus, apklaustieji galèjo ịvertinti, kad sumažejo jų fizinis pajègumas, priverčiantis juos rinktis lengvesnius darbus arba lètinti veiklų atlikimo tempą. Taip pat daugeliui teko keisti laisvalaikio įpročius, renkantis pasyvesnes veiklas.

\section{Literatūra}

1. Lietuvos sveikatos statistika 2012. Lietuvos sveikatos apsaugos ministerija, Higienos instituto Sveikatos informacijos centras. Vilnius, 2013, ISSN 1648-0899.

2. Mills Albert J., Durepos G., Wiebe E. Encyclopedia of Case Study Research. Thematic Analysis. 2010. Online ISBN: 9781412957397 http://dx.doi.org/10.4135/9781412957397

3. Miller Delbert C, Salkind Neil J. Handbook of Research. Design \& Social Measurement. Phenomenology. 2002, Online ISBN: 9781412984386

4. Biber H. The craft of qualitative research. A Holistic Approach, 2005. http://www.sagepub.com/sites/default/files/upm-binaries/6196_Chapter_1_Hesse_Biber_I_Proof.pdf [žiūrèta 2015 $0720]$.

5. Fredriksson-Larsson U, Alsén P, Karlson BW, Brink E. Fatigue two months after myocardial infarction and its relationships with other concurrent symptoms, sleep quality and coping strategies. J Clin Nurs. 2015 May 19. http://dx.doi.org/10.1111/jocn.12876

6. Larsen K.K. Depression following myocardial infarction--an overseen complication with prognostic importance. Dan Med J. 2013 Aug;60(8):B4689. http://www.ncbi.nlm.nih.gov/pubmed/23905572 [žiūrèta 201506 29].

7. Frazier SK, Moser DK, O'Brien JL, Garvin BJ, An K, Macko M. Management of anxiety after acute myocardial infarction. Heart Lung. 2002 Nov-Dec;31(6):411-20. http://www.ncbi. nlm.nih.gov/pubmed/12434142 [žiūrèta 201506 29]. http://dx.doi.org/10.1067/mhl.2002.129445

8. Vasiliauskas D., Jasiukevičienė L., Andziulis A., Šlapikas R., Babarskienė R., Kubilius R. Širdies ir kraujagyslių ligomis sergančių ligonių reabilitacija - naujas požiūris ị stereotipus. Kaunas, 2011; 10-141.

9. Carney RM, Blumenthal JA, Catellier D, Freedland KE, Berkman LF, Watkins LL, Czajkowski SM, Hayano J, Jaffe AS. Depression as a risk factor for mortality after acute myocardial infarction. Am J Cardiol. 2003 Dec 1;92(11):1277-81. http:// www.ncbi.nlm.nih.gov/pubmed/14636903 [žiūrèta 201507 23]. http://dx.doi.org/10.1016/j.amjcard.2003.08.007

10. Kristofferzon M.L., Löfmark R., Carlsson M. Striving for balance in daily life: experiences of Swedish women and men shortly after a myocardial infarction. Journal of Clinical Nursing 2007; 16(2):391-401. http://onlinelibrary.wiley.com/ enhanced/doi/10.1111/j.1365-2702.2005.01518.x/ [žiūrèta 201507 22].

http://dx.doi.org/10.1111/j.1365-2702.2005.01518.x

11. Dodson JA, Arnold SV, Reid KJ, Gill TM, Rich MW, Masoudi FA, Spertus JA, Krumholz HM, Alexander KP. Physical function and independence 1 year after myocardial infarction: observations from the Translational Research Investigating Underlying disparities in recovery from acute Myocardial in- 
farction: Patients' Health status registry. Am Heart J. 2012 May; 163(5): 790-6. http://www.ncbi.nlm.nih.gov/pubmed/22607856 [Žiūrèta 201507 23]

http://dx.doi.org/10.1016/j.ahj.2012.02.024

12. Welin C, Lappas G, Wilhelmsen L. Independent importance of psychosocial factors for prognosis after myocardial infarction. J Intern Med. 2000 Jun; 247(6): 629-39 http://www.ncbi.nlm. nih.gov/pubmed/10886484 [žiūrèta 201507 23] http://dx.doi.org/10.1046/j.1365-2796.2000.00694.x

13. Dodson JA, Arnold SV, Reid KJ, Gill TM, Rich MW, Masoudi FA, Spertus JA, Krumholz HM, Alexander KP. Physical Function and Independence One Year Following Myocardial Infarction: Observations from the TRIUMPH Registry. Am Heart J. 2012 May; 163(5): 790-796. http://www.ncbi.nlm. nih.gov/pmc/articles/PMC3359897/ [žiūrèta 201507 23]. http://dx.doi.org/10.1016/j.ahj.2012.02.024

\section{CHANGES IN INDEPENDENCE, FUNCTIONAL CAPACITY AND ATTITUDE TOWARDS A PERSON IN PATIENTS AFTER MYOCARDIAL INFARCTION DURING A PERIOD OF TREATMENT AND AT HOME}

\section{E. Lamsodienė, G. Juškytė}

Key words: myocardial infarction (MI), independence, functional capacity, activity, attitude towards oneself.

\section{Summary}

According to statistics, around 8 thousand myocardial infarctions are diagnosed in Lithuania every year. It noticeably deteriorates human's activity and a person's life quality, as a result a disability occurs, a blood circulation disorder decreases a person's working activity, so it becomes more difficult to adapt to the environment.

In order to reach the objectives of this research, a phenomenological research method has been used. The semi- structured interview has been used for data collection, this interview covered the following three main parts: independence, functional capacity and attitude towards a person during a period of treatment and at the homes of the individuals who had a myocardial infarction. A questionnaire was drawn up and the respondents were met three times. Each of them had to answer the four following questions:1) What impact has MI had on your independence in your dayto- day activities? 2) How has your physical ability changed at your daily activities? 3) How has your attitude towards yourself changed after MI? 4) What impact will MI have on your working life and leisure time? Unexpected questions motivated respondents to answer as truthfully and in as much depth as possible.

When choosing respondents for this research, they had to meet the following requirements: first - the group should consist of individuals, who had experienced MI within the last 48 hours second - the group should consist of people, who had been undergoing treatment in LSMUL I cardiologic section in April, 2015, third - the group should include individuals who were sent home after the hospital treatment, finally - the group should consist of people who are fully conscious of their situation, environment, themselves and time. Six respondents aged from 45 to 69 (average 57,5 years) participated in this research. They were told about the research including, its purpose and progress. They were also asked to leave their contact numbers so that it was easier to contact them and arrange the meetings. Each interview took around 20 minutes, a recorder was used during the interview, the first two meetings took place in a hospital section that respondents were familiar with. The third meeting was arranged in a place which was convenient for both sides. The first meeting was arranged no more than 48 hours after the respondent had gone to the hospital. The second meeting was arranged on the same day when respondent had been discharged from the hospital (average time is 7 days). The third meeting was after arranged after $7 / 8$ days spent at home.

During each interview, all respondents emphasized changes in their independence, physical ability and attitude towards themselves after MI in different periods of recovery. 15 sub- themes were picked out during the initial coding. They got expedient titles. Thereafter, every sub- theme was attributed to the following 3 major themes: a) a change of independence; b) changes in physical ability; c) thoughts, feelings and emotions.

All individuals participating in this research admitted that they did not feel any major changes in their day- to- day activities during the first two days after MI. However, they have acknowledged that it is difficult to assess their potential realistically as there is a lack of physical activities in a hospital.

Respondents who had experienced MI after still being in a hospital admitted feeling anxiety about the future and health changes for the worse. They also expressed uncertainty about their future performance in life and they also expressed negative thoughts, regarding employment opportunities.

Respondents who had experienced MI and participated in this research expressed both positive and negative attitudes towards themselves: the burden of household and etc.

Individuals could evaluate a decrease in their physical ability only when they came back home. This factor made many decide it was easier to them to work less or lower the pace of activities.

Correspondence to: evelina.lamsodiene@go.kauko.lt

Gauta 2015-09-10 